\begin{abstract}
THE LIMITS OF DROUGHT-INDUCED RAPID COLD-HARDENING: EXTREMELY BRIEF, MILD DESICCATION TRIGGERS ENHANCED FREEZE-TOLERANCE IN EUROSTA SOLIDAGINIS LARVAE
\end{abstract}

by J.D. Gantz

Rapid cold-hardening $(\mathrm{RCH})$ is a highly conserved response in insects that induces physiological changes within minutes to hours of exposure to low temperature and provides protection from chilling injury. Recently, a similar response, termed drought-induced $\mathrm{RCH}$, was described following acute desiccation. In this study, we investigated the limits and mechanisms of this response in larvae of the goldenrod gall fly Eurosta solidaginis. The cold-hardiness of larvae increased after as few as $2 \mathrm{~h}$ of desiccation and a loss of less than $1 \%$ fresh mass, as organismal survival increased from $8 \%$ to $41 \%$ following exposure to $-18^{\circ} \mathrm{C}$. We also demonstrated that drought-induced RCH occurs independently of neuroendocrine input, as midgut tissue desiccated ex vivo displayed improved freeze-tolerance relative to control tissue. Our results indicate that $E$. solidaginis larvae are extremely sensitive to desiccation stress, which is a triggering mechanism for one or more physiological pathways that confer enhanced freeze-tolerance. 


\title{
THE LIMITS OF DROUGHT-INDUCED RAPID COLD-HARDENING: EXTREMELY BRIEF, MILD DESICCATION TRIGGERS ENHANCED FREEZE-TOLERANCE IN EUROSTA SOLIDAGINIS LARVAE
}

\author{
A thesis. \\ Submitted to the \\ Faculty of Miami University \\ in partial fulfillment of \\ the requirements for the degree of \\ Master of Science \\ Department of Biology \\ by \\ Josiah David Gantz \\ Miami University \\ Oxford, Ohio \\ 2014
}

Advisor: Richard E. Lee Jr.

Reader: Jon Costanzo

Reader: Paul Schaeffer 


\section{Table of Contents}

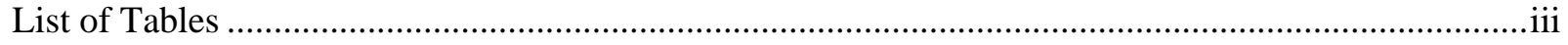

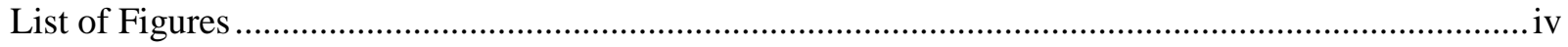

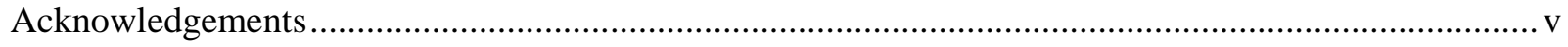

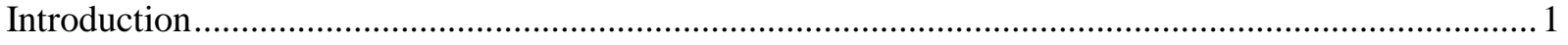

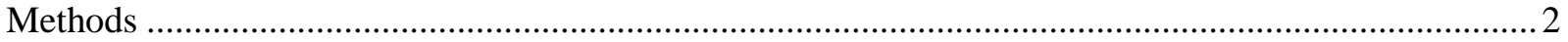

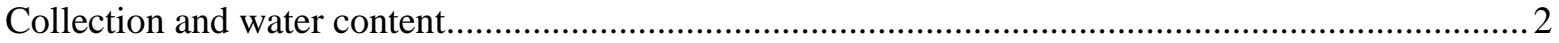

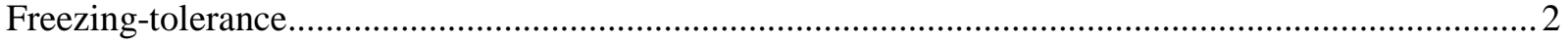

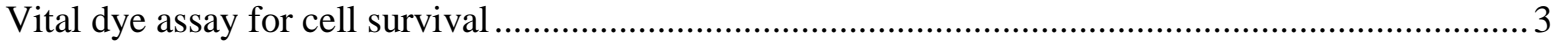

Treatments to induce $\mathrm{RCH}$

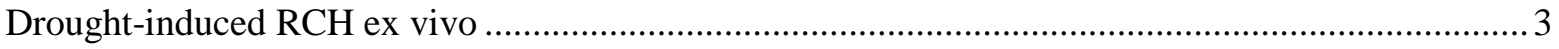

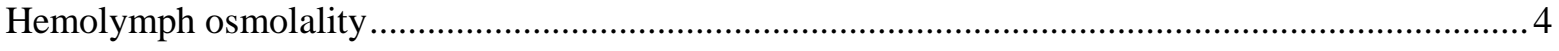

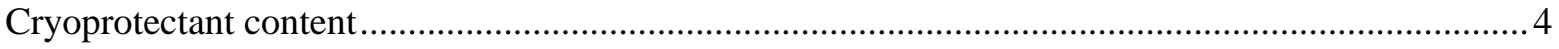

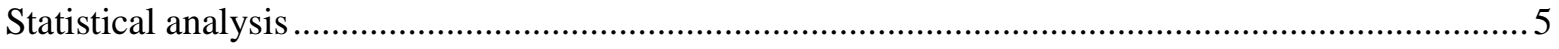

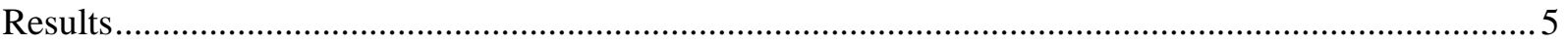

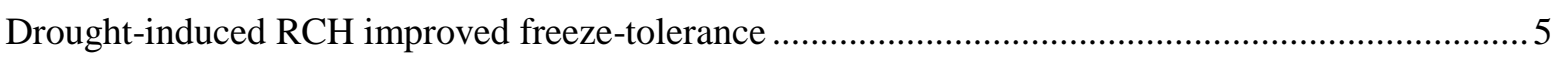

Drought-induced RCH enhanced tissue cold-hardiness ex vivo ................................................ 6

Hemolymoph osmolality and cryoprotectant levels .................................................................. 6

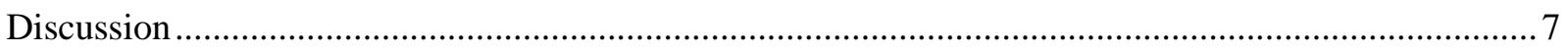

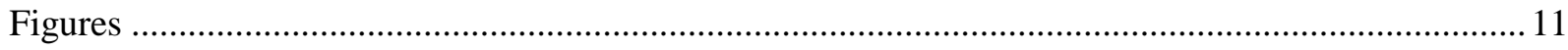

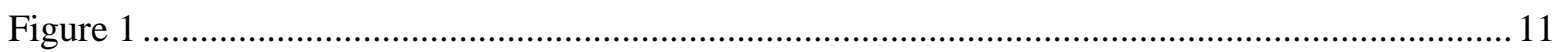

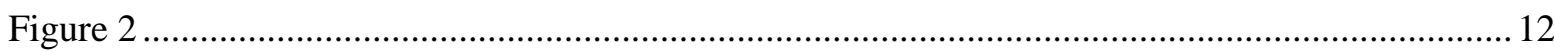

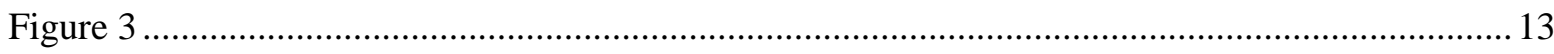

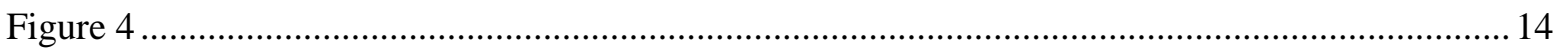

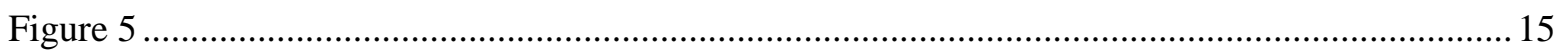

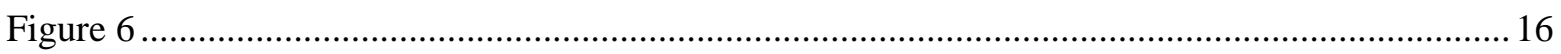

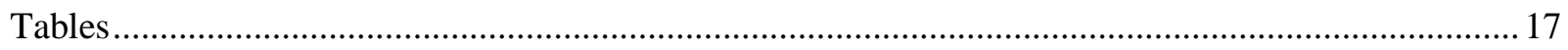

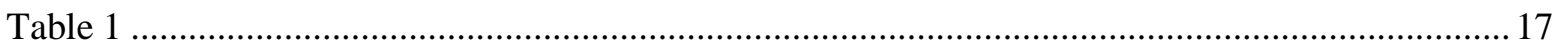

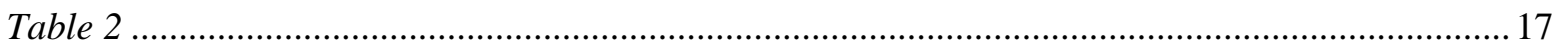

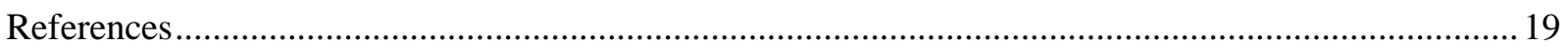




\section{List of Tables}

Table 1. Changes in hemolymph osmolality elicited by drought-induced RCH in larvae collected and treated in mid-October. Hemolymph was pooled from 2-3 larvae as needed; $n=6$ per treatment. All treatments lasted $2 \mathrm{~h}$ unless noted. Control larvae were untreated. Predicted osmolality is calculated based on the control group measured hemolymph osmolality and the percent body water lost. Measured hemolymph osmolality values are mean \pm SEM. Statistical significance $(\mathrm{p} \leq 0.05)$ is denoted by $*$ and indicates the mean measured hemolymph osmolality of the treatment is distinguishable from the control. Page 17.

Table 2. Cryoprotectant concentrations $\left(\mu \mathrm{mol} \mathrm{ml}^{-1}\right)$ in larvae collected and treated in midOctober. All treatments $(n=6)$ lasted $2 \mathrm{~h}$, unless noted. Control larvae were untreated. No treatment elicited significant differences from controls $(\mathrm{p} \leq 0.05)$. Page 18. 


\section{List of Figures}

Figure 1. Desiccation for as little as $2 \mathrm{~h}$ significantly enhanced larval E. solidaginis tolerance of freezing at $-18^{\circ} \mathrm{C}$ for $24 \mathrm{~h}$. Larvae $(\mathrm{n} \geq 26)$ were desiccated at $0 \% \mathrm{RH}$. Treatments $( \pm \mathrm{SEM})$ sharing a letter were not statistically distinguishable $(\mathrm{p}=0.05)$. Page 11 .

Figure 2. Severity of desiccation had no effect on larval E. solidaginis tolerance of freezing at $18^{\circ} \mathrm{C}$ for $24 \mathrm{~h}$. Larvae $(\mathrm{n} \geq 26)$ were exposed to $0^{\circ} \mathrm{C}, 0 \% \mathrm{RH}$ and $0^{\circ} \mathrm{C}$ simultaneously, and desiccated at $0 \%, 33 \%$, and $75 \% \mathrm{RH}$ for $2 \mathrm{~h}$. Treatments ( $(\mathrm{SEM})$ sharing a letter were not statistically distinguishable $(\mathrm{p}=0.05)$. Page 12 .

Figure 3. Severity of desiccation had no effect on freezing tolerance of larval E. solidaginis fat body or midgut tissue. Larvae $(\mathrm{n} \geq 3)$ were exposed to $0^{\circ} \mathrm{C}, 0 \% \mathrm{RH}$ or $0^{\circ} \mathrm{C}$ simultaneously, and desiccated at $0 \%, 33 \%$, or $75 \% \mathrm{RH}$ for $2 \mathrm{~h}$ following which the appropriate tissues were excised and frozen at $-18^{\circ} \mathrm{C}$ for $24 \mathrm{~h}$. Analysis was carried out within tissue types. * denotes $\mathrm{p} \leq 0.05$. Page 13.

Figure 4. Desiccation for as little as $1 \mathrm{~h}$ significantly enhanced larval E. solidaginis fat body and midgut tissue tolerance of freezing. Larvae $(n \geq 3)$ were desiccated at $0 \% \mathrm{RH}$ for various durations, following which tissues were excised and frozen at $-18^{\circ} \mathrm{C}$ for $24 \mathrm{~h}$. Treatments $( \pm$ SEM) sharing a letter were not statistically distinguishable $(\mathrm{p}=0.05)$. Page 14 .

Figure 5. Severity of desiccation had no effect on freezing tolerance of larval E. solidaginis fat body or midgut tissue cold-tolerance. Tissues from 3-5 larvae were excised and dehydrated ex vivo at 75,85 , and $98 \% \mathrm{RH}$ for $2 \mathrm{~h}$ following which they were frozen at $-18^{\circ} \mathrm{C}$ for $24 \mathrm{~h}$. Analysis was carried out within tissue types. * denotes $\mathrm{p} \leq 0.05$. Page 15 .

Figure 6. Desiccation for as little as $1 \mathrm{~h}$ significantly enhanced larval E. solidaginis fat body tissue tolerance of freezing. Tissues from 3-5 larvae were excised and dehydrated ex vivo at 75\% $\mathrm{RH}$, following which the tissues were frozen at $-18^{\circ} \mathrm{C}$ for $24 \mathrm{~h}$. Treatments $( \pm \mathrm{SEM})$ sharing a letter were not statistically distinguishable $(\mathrm{p}=0.05)$. Page 16. 


\section{Acknowledgements}

This research was funded by the National Science Foundation (\#IOB-0416720). The authors would like to acknowledge Dr. Shuxia Yi, John Fowler, and Nicholas Van Benschoten for help with collection of goldenrod galls and Dr. Jon Costanzo and Dr. Paul Schaeffer for their critical review of this manuscript. We also thank Michael Hughes of the Statistical Consulting Center at Miami University for his assistance with statistical analysis. 


\section{Introduction}

Insects have a remarkable ability to rapidly adjust to changing ambient conditions. This ability, called rapid cold-hardening $(\mathrm{RCH})$, induces physiological changes within minutes to hours, increasing survival while protecting against damage from cold shock (Chen et al., 1987; Lee et al., 1987; Overgaard et al., 2007). Traditionally, RCH has been studied as a response to brief exposure to sub-lethal chilling; however, $\mathrm{RCH}$-like responses can also be induced by acute exposure to heat and anoxia (Chen et al., 1987; Coulson and Bale, 1991). Recently, droughtinduced RCH was described following brief exposure to desiccation stress (Levis et al., 2012; Sinclair and Chown, 2003).

Despite the generality of $\mathrm{RCH}$ in insects, little is known about underpinning mechanisms and, due to its novelty, drought-induced $\mathrm{RCH}$ is even more poorly understood. However, while investigating drought-induced RCH in Eurosta solidaginis larvae, Levis et al. (2012) noted an increase in hemolymph osmolality that was not attributable to either the osmo-concentration of solutes during drying or the synthesis of glycerol. During seasonal cold-hardening, many insects accumulate low molecular mass polyols and sugars that function to stabilize membrane and protein structures, act as a replacement for water, and colligatively depress freezing points and reduce water loss (Crowe et al., 1988; Salt, 1961; Duman, 1977; Duman and Horwath, 1983). Despite the nearly ubiquitous synthesis and accumulation of cryoprotectant compounds during winter cold-hardening, there is no consistent sugar or polyol response associated with RCH (Lee and Denlinger, 2010).

While seasonal cold-hardening is thought to be hormonally regulated, $\mathrm{RCH}$ can occur independently of input from the neuroendocrine system, as excised tissues can be treated ex vivo to induce RCH (Yi and Lee, 2003; 2004). Further, Teets et al. (2008) demonstrated that coldsensing at the cellular level is mediated by temperature-driven calcium flux. Calcium is a known activator of the p38 mitogen-activated protein kinase (p38 MAPK) pathway, which modulates cellular activity independently of neuroendocrine input and is activated during RCH induction in the freeze-intolerant flesh fly, Sarcophaga crassipalpis (Fujiwara and Denlinger, 2007; Teets et al., 2008). Due to the rapidity of the response, it seems likely that drought-induced RCH may also be sensed and induced at the cellular level in a similar manner.

The goldenrod gall fly, E. solidaginis, is widespread in eastern North America, ranging from Florida to Texas and north into southern Canada (Uhler, 1951). Larvae develop and 
overwinter in stem galls on goldenrod plants (Solidago spp.). Throughout the summer and earlyto-mid autumn, larvae are susceptible to desiccation if removed from the high humidity environment in their galls (Williams et al., 2004; Williams and Lee, 2005). In winter, coldhardened larvae are more resistant to desiccation than all but the most xeric-adapted insects (Ramlov and Lee, 2000). During the transition from summer to winter, larvae gradually acquire desiccation tolerance. For a few weeks in September and October, they are hardy enough to readily survive exposure to acute stresses, yet are not so resistant to water loss as to render rapid dehydration impossible (Rojas et al., 1986; Williams et al., 2004; Williams and Lee, 2005).

To better understand drought-induced $\mathrm{RCH}$ and to compare chilling and desiccation as $\mathrm{RCH}$-induction triggers, we characterized the thresholds of drought-induced $\mathrm{RCH}$ relative to the duration of exposure and magnitude of desiccation in September and October collected $E$. solidaginis larvae. We also examined the effects of acute desiccation stress in fat body and midgut tissues ex vivo. Lastly, we investigated select cryoprotectants to determine the source of the observed increase in hemolymph osmolality.

\section{Methods}

\section{Collection and water content}

Spherical galls containing E. solidaginis larvae were collected from goldenrod plants in Butler County, Ohio. Galls were collected from early September through mid-October, 2013. During these few weeks, larvae were an appropriate size for experimentation $(\geq 25 \mathrm{mg})$ and had not yet developed the extreme desiccation resistance that results from winter cold-hardening. Larvae were removed from their galls and weighed. Following each treatment, larvae were dried at $65^{\circ} \mathrm{C}$ until they reached a constant mass. Water content was determined by the difference between initial mass and dry mass. When appropriate, larvae were flash frozen in liquid nitrogen $\left(-196^{\circ} \mathrm{C}\right)$ and then held at $-80^{\circ} \mathrm{C}$ until needed.

\section{Freezing-tolerance}

Larvae were exposed to discriminating cold temperature by placing them in $0.6 \mathrm{ml}$ microcentrifuge tubes in a programmable refrigerated bath. Larvae were placed in contact with a small piece of ice during cooling, thus inoculating internal ice formation near the freezing point of the hemolymph. A critical test temperature was selected such that control larvae experienced 
$\sim 20 \%$ survival after $24 \mathrm{~h}$ of chilling. During our study, this temperature decreased from $-15^{\circ} \mathrm{C}$ to $-20^{\circ} \mathrm{C}$ as field-collected larvae progressively increased their cold-hardiness in preparation for winter. Survival was determined by response to tactile stimulation following a $2 \mathrm{~h}$ recovery at room temperature.

\section{Vital dye assay for cell survival}

Fat body and midgut tissues were dissected from larvae in Coast's solution (Coast, 1988). Cell membrane integrity was determined using the LIVE/DEAD sperm viability kit (Molecular Probes, Eugene, OR) as adapted by Yi and Lee (2003). In this assay, tissues were incubated in SYBR-14, a membrane-penetrating green fluorescent dye, and propidium iodide, a nonpenetrating red fluorescent dye. Cells with intact membranes excluded the propidium iodide and fluoresced green, while those that sustained membrane damage appeared red-orange. During microscopy, we counted living and dead cells visible within the field of view. Three-to-four frames containing at least 50 cells were counted per tissue and the results were compiled to determine a rate of survival for the tissue in one larva. These results were averaged for 3-4 larvae for each treatment and are expressed as a percentage of the cells that remained impermeable to propidium iodide.

\section{Treatments to induce $\mathrm{RCH}$}

Cold-induced RCH larvae were placed in plastic weighing dishes and subjected to a mild cold treatment $\left(0^{\circ} \mathrm{C}\right)$ for $2 \mathrm{~h}$ on ice. The thresholds of drought-induced $\mathrm{RCH}$ were determined by exposing groups of larvae to desiccation treatments of varying duration and relative humidity. Desiccation treatments lasted between $0.5 \mathrm{~h}$ and $12 \mathrm{~h}$. Anhydrous calcium sulfate (Drierite ${ }^{\circledR}$ ) and saturated salt solutions were used in sealed desiccating chambers to create different environments: Drierite ${ }^{\circledR}(0 \% \mathrm{RH}), \mathrm{MgCl}_{2}$ (33\% RH), $\mathrm{NaCl}(75 \% \mathrm{RH}), \mathrm{KCl}(85 \% \mathrm{RH})$, or $\mathrm{K}_{2} \mathrm{SO}_{4}$ (98\% RH) (Greenspan, 1977). After treatment, freezing-tolerance was determined as previously described.

\section{Drought-induced RCH ex vivo}

To determine if drought-induced $\mathrm{RCH}$ can occur independently of the neuroendocrine system, target tissues were rapidly dehydrated ex vivo. Excised tissues were placed in a small 
plastic weighing dish and completely submerged in 80-100 $\mu$ l of hemolymph pooled from $E$. solidaginis larvae. The dish containing the sample was transferred to a humidity-controlled desiccation chamber, as described above, and incubated for $30 \mathrm{~min}, 1 \mathrm{~h}, 2 \mathrm{~h}$, or $3 \mathrm{~h}$. During incubation, water evaporated from the hemolymph, resulting in the concentration of solutes and exposing the tissue to osmotic stress that mimicked the effect of organismal dehydration. Following desiccation, tissues were placed in a microcentrifuge tube in Coast's solution and frozen at an appropriate discriminating low temperature. The vital dye assay was then performed to assess tissue-level damage as previously described.

\section{Hemolymph osmolality}

Hemolymph osmolality was measured by drawing hemolymph into a microcapillary tube through an incision in the larval cuticle. Hemolymph was pooled from 2-3 larvae to obtain a sufficient volume for measurement. Osmolality was measured using a Model 3320 freezing-point depression osmometer (Advanced Instruments Inc., Norwood, MA).

\section{Cryoprotectant content}

Whole larvae were weighed and stored at $-80^{\circ} \mathrm{C}$ until cryoprotectant content was assessed. Larvae were homogenized in $0.6 \mathrm{~N}$ perchloric acid (PCA) to extract metabolites and the neutralized extract was used for each of the assays. Glycerol content was determined using the method described by Holmstrup et al. (1999). Briefly, $800 \mu \mathrm{l}$ of glycerol free reagent (Sigma-Aldrich Chemical Company, Saint Louis, MO \#F6428) was reconstituted and added to $200 \mu \mathrm{l}$ aliquots of PCA extract. Following a 15 -min incubation at $37^{\circ} \mathrm{C}$, absorbance was read at $540 \mathrm{~nm}$ on a Jenway model $6705 \mathrm{UV} / \mathrm{Vis}$ spectrophotometer.

Trehalose and glucose levels were measured by aliquotting PCA extract into $100 \mu \mathrm{l}$ portions for trehalose and glucose determination. Trehalose samples were treated with trehalase (Sigma Chemical Co. \# T8778) diluted to a concentration of 0.2 units/ml in $135 \mathrm{mM}$ citric acid buffer ( $\mathrm{pH}$ 5.7), and incubated overnight at $37^{\circ} \mathrm{C}$ to cleave trehalose molecules into two glucose subunits. The samples were analyzed using a colorimetric glucose assay kit (Sigma Chemical Co. \# GAGO20) and absorbance was read at $540 \mathrm{~nm}$. Trehalose content was determined by the difference in absorbance between trehalase-treated and untreated fractions. 
Sorbitol content was measured using the enzymatic assay from Bergmeyer et al. (1974). Briefly, a reaction mixture containing $500 \mu 1$ PCA extract, $1000 \mu 10.1 \mathrm{M}$ sodium pyrophosphate, and $50 \mu 130 \mathrm{mM} \mathrm{NAD}$ was prepared. The absorbance of this mixture was measured at $340 \mathrm{~nm}$, before $25 \mu 1$ sorbitol dehydrogenase ( $5 \mathrm{mg}$ protein/ml) was added. Following a 60 -min incubation at $\sim 22^{\circ} \mathrm{C}$, absorbance was read again at $340 \mathrm{~nm}$.

\section{Statistical analysis}

All data were analyzed using R (R Foundation for Statistical Computing, Vienna, Austria). Organismal and tissue survival rates were analyzed using binomial logistic regression with a post hoc Bonferroni correction. Cryoprotectant levels and changes in hemolymph osmolality passed the Shapiro-Wilk test for normality $(\mathrm{p}<0.05)$ and were analyzed with one-way analysis of variance tests with Bonferroni multiple comparisons corrections.

\section{Results}

\section{Drought-induced RCH improved freeze-tolerance}

At the organismal level, exposure to acute desiccation significantly improved larval freeze-tolerance in as little as $2 \mathrm{~h}$ (Figs. 1 and 2). Survival of freezing improved from $\sim 8 \%$ to over $40 \%$ in September-collected larvae following $2 \mathrm{~h}$ of desiccation at 0,33 or $75 \% \mathrm{RH}$ (p<0.01; Fig. 1). In the 2-h treatments at 33\% and $75 \%$ RH, larvae lost less than $1 \%$ of their fresh mass $(0.85 \%$ and $0.68 \%$, respectively), whereas the $0 \% \mathrm{RH}$ treatment produced a loss of $3.3 \%$ fresh mass. Chilling at $0^{\circ} \mathrm{C}$ for $2 \mathrm{~h}(\mathrm{RCH})$ and simultaneous chilling and desiccation at $0^{\circ} \mathrm{C}$ and $0 \% \mathrm{RH}(\mathrm{D}+\mathrm{RCH})$ did not significantly affect survival (Fig. 1). Among 0\% RH treatments, both 2 $\mathrm{h}$ and $4 \mathrm{~h}$ of desiccation significantly enhanced freeze-tolerance (Fig. 2). Shorter exposure to desiccation did not significantly improve survival. Larvae desiccated for $12 \mathrm{~h}$, resulting in a loss of $7.3 \%$ of fresh mass, were no more freeze-tolerant than controls (Fig. 2).

These organismal-level observations were corroborated by measures of cell viability in fat body and midgut tissues (Figs. 3 and 4). Survival rates of midgut cells from larvae desiccated for $2 \mathrm{~h}$ at 0,33 and $75 \% \mathrm{RH}$ improved from 57\% to 94, 95, and 92\%, respectively ( $\mathrm{p}<0.01$; Fig. 3). Further, $2 \mathrm{~h} \mathrm{RCH}$ and $\mathrm{D}+\mathrm{RCH}$ treatments improved cellular survival at 85 and $90 \%$, respectively $(\mathrm{p}<0.01)$. Fat body cells exhibited similar, but less dramatic improvements in survival. 
Midgut cells from larvae exposed to $0 \%$ RH displayed significantly improved freezing tolerance following as little as $1 \mathrm{~h}(\mathrm{p}<0.01)$ and the difference remained significant following treatments as long as $12 \mathrm{~h}$ ( $\mathrm{p}<0.05$; Fig. 4). While $12 \mathrm{~h}$ of desiccation at $0 \%$ RH improved survival relative to controls, cold-hardiness was significantly lower in this treatment group than in larvae desiccated for $2 \mathrm{~h}$ at $0 \% \mathrm{RH}(\mathrm{p}<0.01)$.

\section{Drought-induced RCH enhanced tissue cold-hardiness ex vivo}

Due to mechanical damage to tissues caused by handling, we were not able to measure the amount of water lost per tissue sample during ex vivo desiccation. In lieu of a direct measure of tissue water loss, we measured changes in the osmotic pressure of the hemolymph in which the tissues were bathed. Since this mirrors natural conditions by relying on the increasing concentration of solutes in the hemolymph to dehydrate the tissues, we used this method as a proxy for organismal dehydration. The increases in hemolymph osmolality were approximately linear during our $3 \mathrm{~h}$ desiccation treatments, averaging $\sim 100,61$, and $25 \mathrm{mOsm} \mathrm{kg}^{-1}$ per hour at 75,85 , and $98 \% \mathrm{RH}$, respectively. Assuming an initial hemolymph osmolality of $\sim 600$ mOsm $\mathrm{kg}^{-1}$, these rates translate to $16.7,10.2$, and $4.2 \%$ water loss per hour, respectively.

Fat body and midgut tissues desiccated ex vivo rapidly cold-hardened in the absence of a connection to the neuroendocrine system. Midgut tissue desiccated at $75 \% \mathrm{RH}$ for $2 \mathrm{~h}$ improved from 11 to $78 \%$ survival relative to controls ( $<<0.05$; Fig. 5). Desiccation for $2 \mathrm{~h}$ at 85 and $98 \%$ RH improved survival of midgut cells from $11 \%$ to 74 and $45 \%$, respectively ( $<<0.05$ ). Again, fat body tissues exhibited similar, but less pronounced improvements in cold-hardiness. Further, fat body tissues showed significantly improved cold-hardiness following pre-treatments of $1 \mathrm{~h}, 2$ $\mathrm{h}$, and $3 \mathrm{~h}$ at $75 \% \mathrm{RH}(\mathrm{p}<0.05)$, while midgut tissues had significantly enhanced survival after 2 $\mathrm{h}$ and $3 \mathrm{~h}(\mathrm{p}<0.01$; Fig. 6).

\section{Hemolymoph osmolality and cryoprotectant levels}

Brief desiccation elevates E. solidaginis hemolymph osmolality beyond the effects of osmo-concentration of solutes; however, the solute(s) driving this increase is not known (Levis et al., 2012). In our study, we found $\sim 80 \mathrm{mOsm} \mathrm{kg}^{-1}$ increase in hemolymph osmolality within $4 \mathrm{~h}$ of desiccation, whereas the effects of dehydration only explained a change of $\sim 20 \mathrm{mOsm} \mathrm{kg}{ }^{-1}$ $(\mathrm{p}<0.01$; Table 1). Further, hemolymph osmolality was significantly elevated following $2 \mathrm{~h}$ of 
simultaneous exposure to low temperature and desiccation $\left(0^{\circ} \mathrm{C}\right.$ and $\left.0 \% \mathrm{RH}\right)(\mathrm{p}<0.05$; Table 1$)$. In order to determine the cause of the increase in hemolymph osmolality, we measured the levels of four commonly accumulated cryoprotectants: glucose, trehalose, sorbitol, and glycerol. Acute desiccation did not elicit significant changes in the level of any of these compounds (Table 2).

\section{Discussion}

Freezing and dehydration present many of the same physiological challenges; thus, adjustments made to contend with desiccation stress often increase cold-tolerance as well (Block, 1996; Danks, 2000; Ring and Danks, 1994; Williams et al., 2004). For example, long-term drought-acclimation decreases the lower lethal temperature of the soil collembolan Folsomia candida by $\sim 6^{\circ} \mathrm{C}$ (Bayley and Holmstrup, 1999) and slow desiccation over the course of $2 \mathrm{~d}$ enhances freeze-tolerance in B. antarctica (Hayward et al., 2007). The interplay between desiccation and cold-tolerance is usually attributed to the induction of seasonal cold-hardening and to the effects of osmo-concentration of solutes within the body (Holmstrup et al., 2010). However, as few as $6 \mathrm{~h}$ of dehydration significantly enhances freezing tolerance in larvae of $E$. solidaginis and Pringleophaga marioni, suggesting that brief desiccation can trigger an RCHlike response (Levis et al., 2012; Sinclair and Chown, 2003). In this study, we defined the minimum amount of dehydration required to trigger $\mathrm{RCH}$ in E. solidaginis larvae. Desiccation for $1 \mathrm{~h}$ markedly improved freeze-tolerance in fat body and midgut tissues and increased organismal freezing tolerance within $2 \mathrm{~h}$. Further, the protection afforded by dehydration was maximized within $2 \mathrm{~h}$; that is, the rate of survival was not further improved by desiccating larvae for longer periods of time. These results closely resemble the timing of chilling-induced $\mathrm{RCH}$ with respect to the rate of induction and the time required to fully activate this response (Lee and Denlinger, 2010).

Reduced body water content decreases the amount of damage sustained during freezing by concentrating solutes within the body, which colligatively depresses the freezing point, tempers ice formation, and helps to stabilize membrane proteins (Holmstrup et al., 2010). Even slight increases in solute concentrations (i.e. 10-30 mM) can be beneficial during bouts of low temperature (Carpenter and Crowe, 1988). Sugars and polyols accumulated in low concentrations do not have significant effects on the colligative properties of hemolymph; however, they can improve cold-tolerance by stabilizing membrane and proteins structures and 
acting as a replacement for water (Carpenter and Crowe, 1988; Crowe et al., 1988). Thus, it was unclear whether drought-induced $\mathrm{RCH}$ is a result of the effects of modest osmo-concentration of body water or if a physiological response is triggered by slight desiccation. To answer this question, we investigated how the amount of water lost during dehydration affects freezetolerance. Organismal and cellular survival rates were nearly identical among treatment groups desiccated for $2 \mathrm{~h}$ at 0,33 , or $75 \% \mathrm{RH}$. Remarkably, larvae desiccated at $75 \% \mathrm{RH}$ lost only $0.68 \%$ of their fresh mass on average, and survived at the same rate as larvae desiccated at $0 \%$ $\mathrm{RH}$, which lost $3.34 \%$ of their fresh mass (Figs. 2 and 3). If the protective effects of dehydration are a result of the concentration of solutes via the removal of body water alone, survival rates should be influenced by the severity of dehydration. Since our data demonstrate that the efficacy of drought-induced $\mathrm{RCH}$ was independent of the amount of water lost, we conclude that this is a physiological response that is triggered by even slight desiccation.

Drought-induced $\mathrm{RCH}$ is similar to chilling-induced $\mathrm{RCH}$ in that it can occur independently of the neuroendocrine system. Brief chilling enhances the cold-tolerance of isolated tissues, indicating that $\mathrm{RCH}$ operates, at least in part, independently of neuroendocrine input (Watanabe et al., 2002; Yi and Lee, 2003; 2004). In our study, ex vivo desiccation at $75 \%$ $\mathrm{RH}$ enhanced freeze-tolerance in isolated fat body tissues within $1 \mathrm{~h}$ and in midgut tissues within 2 h (Fig. 6).

To respond to such external stressors without mediation from the neuroendocrine system, tissues must be able to intrinsically sense the stress and respond appropriately. Calcium flux, likely caused by temperature-dependent changes in cellular ion transport or membrane permeability, is the first step in cold-sensing at the cellular level (Teets et al., 2008; 2013). Dehydration-sensing at the cellular level may occur in a similar manner. The hydration status of a membrane affects its permeability and can alter the functioning of associated proteins (Hazel and Williams, 1990; M'Baye et al., 2008). Since a concentration gradient of calcium ions is maintained across cellular membranes via active transport by integral proteins, small changes in hydration could affect protein or membrane activity and result in an influx of calcium ions into the cell, triggering the $\mathrm{RCH}$ response.

Beyond the role of calcium, we have limited understanding of the mechanisms involved in $\mathrm{RCH}$. Although cryoprotective sugars and polyols are accumulated to counteract long-term desiccation and low temperature stress (Kostal et al., 2001; Lee and Denlinger, 1991; Salt, 1961), 
there is no consistent polyol or sugar response among species exhibiting RCH (Lee and Denlinger, 2010). While it is unclear what role cryoprotectants play in rapid physiological responses, Levis et al. (2012) found a significant increase in hemolymph osmolality during drought-induced $\mathrm{RCH}$ in E. solidaginis larvae. We observed similar increases following desiccation as brief as $4 \mathrm{~h}$. October-collected larvae lost an average of $3.6 \%$ of their body water during $4 \mathrm{~h}$ desiccation at $0 \% \mathrm{RH}$ (Table 1). This treatment yielded an $83 \mathrm{mOsm} \mathrm{kg}^{-1}$ increase in hemolymph osmolality, whereas we would expect only a $21 \mathrm{mOsm} \mathrm{kg}^{-1}$ increase based on the effects of dehydration alone. Such an increase in hemolymph osmolality could be explained by the production of cryoprotectants; however, concentrations of glucose, trehalose, glycerol, and sorbitol, the four primary cryoprotective compounds used by E. solidaginis, were unaffected by acute desiccation (Table 2).

The increase in hemolymph osmolality associated with drought-induced RCH might be explained by elevated levels of free amino acids that are known to affect cold and freezing tolerance (Karow, 1991). Further, alanine and glutamine concentrations increase nearly twofold during RCH in flesh flies (Michaud and Denlinger, 2007) and a proline-augmented diet allows the normally freeze-intolerant fruit fly, Drosophila melanogaster, to tolerate freezing of $50 \%$ of its body water (Kostal et al., 2012). Levels of free amino acids can be regulated by autophagy, a cellular process that degrades damaged or unnecessary macromolecules and organelles, freeing their components for use elsewhere (Maiuri et al., 2007; Meijer and Dubbelhuis, 2004; Onodera and Ohsumi, 2005; Rabinowitz and White, 2010). Autophagy is constitutively active in most cells (Hosokawa et al., 2006; Rabinowitz and White, 2010). Thus, modest increases in its activity would not require the production of new cellular machinery, which is important since $\mathrm{RCH}$ occurs even when protein synthesis is inhibited (Misener et al., 2001). Further, autophagic proteolysis is triggered by even small changes in cell volume, can degrade up to $5 \%$ of cytosolic protein per hour, and is upregulated during long-term desiccation in B. antarctica (Prick et al., 2006, Teets et al., 2012).

Drought-induced RCH displays remarkable similarities to RCH triggered by chilling, which begs the question: Does acute desiccation trigger the same physiological response that is activated by chilling, or is drought-induced $\mathrm{RCH}$ one of multiple, subtly different responses activated by stressors such as heat, chilling, desiccation, or anoxia? As discussed above, coldactivated calcium flux is the putative first step in the RCH signaling cascade (Teets et al., 2008; 
2013). Calcium mediates the activation of $\mathrm{p} 38$ MAPK, a class of mitogen-activated protein kinases that responds to a variety stresses, and chilling stimulates the phosphorylation of p38 MAPK within $10 \mathrm{~min}$ in S. crassipalpis (Fujiwara and Denlinger, 2007; Teets et al., 2013). Under hypertonic conditions, both p38 MAPK and the related, stress-responsive ERK1/2 MAPK are activated within $10 \mathrm{~min}$ in mammalian systems (Itoh et al., 1994; Shrode et al., 1998; Wehner et al., 2003). This suggests that both chilling and desiccation stresses trigger the same secondmessenger cascades. It must be noted, however, that cellular signaling processes are complex; often, many pathways are activated simultaneously with extensive interplay among them (Wehner et al., 2003). Thus, we cannot rule out the possibility that MAPK activation is a common characteristic of two distinct mechanisms.

Our results show that very brief exposure to desiccating conditions elicits a physiological response that significantly enhances $E$. solidaginis freeze-tolerance. Fall-collected larvae were exquisitely sensitive to dehydration stress, as a loss of less than $1 \%$ of their fresh mass was sufficient to trigger $\mathrm{RCH}$. This extreme sensitivity to dehydration suggests that insects track changes in humidity, perhaps using such cues as a means to select favorable microhabitats for temporarily stressful conditions or overwintering. Additionally, insects might alter their coldhardiness in response to humidity changes as they move from one microhabitat to another. While E. solidaginis larvae do not change microhabitats, the conditions they are exposed to within a gall change dramatically during autumn. For most of their development, larvae are protected from desiccating conditions by the hydrated, living gall tissue surrounding them; however, during fall, the host plant senesces and begins to dry (Rojas et al., 1986; Williams and Lee, 2005). By winter, when the desiccated plant tissue offers little protection from the elements, larvae have entered diapause and acquired extreme resistance to evaporative water loss (Rojas et al., 1986; Williams et al., 2004; Williams and Lee, 2005). Between the early stages of senescence of the host plant and acquisition of maximal desiccation resistance, larvae are under dehydration stress. Thus, drought-induced RCH may be an important component of the successful transition from summer growth and development to winter-hardened, diapausing larvae. 
Figures

Figure 1

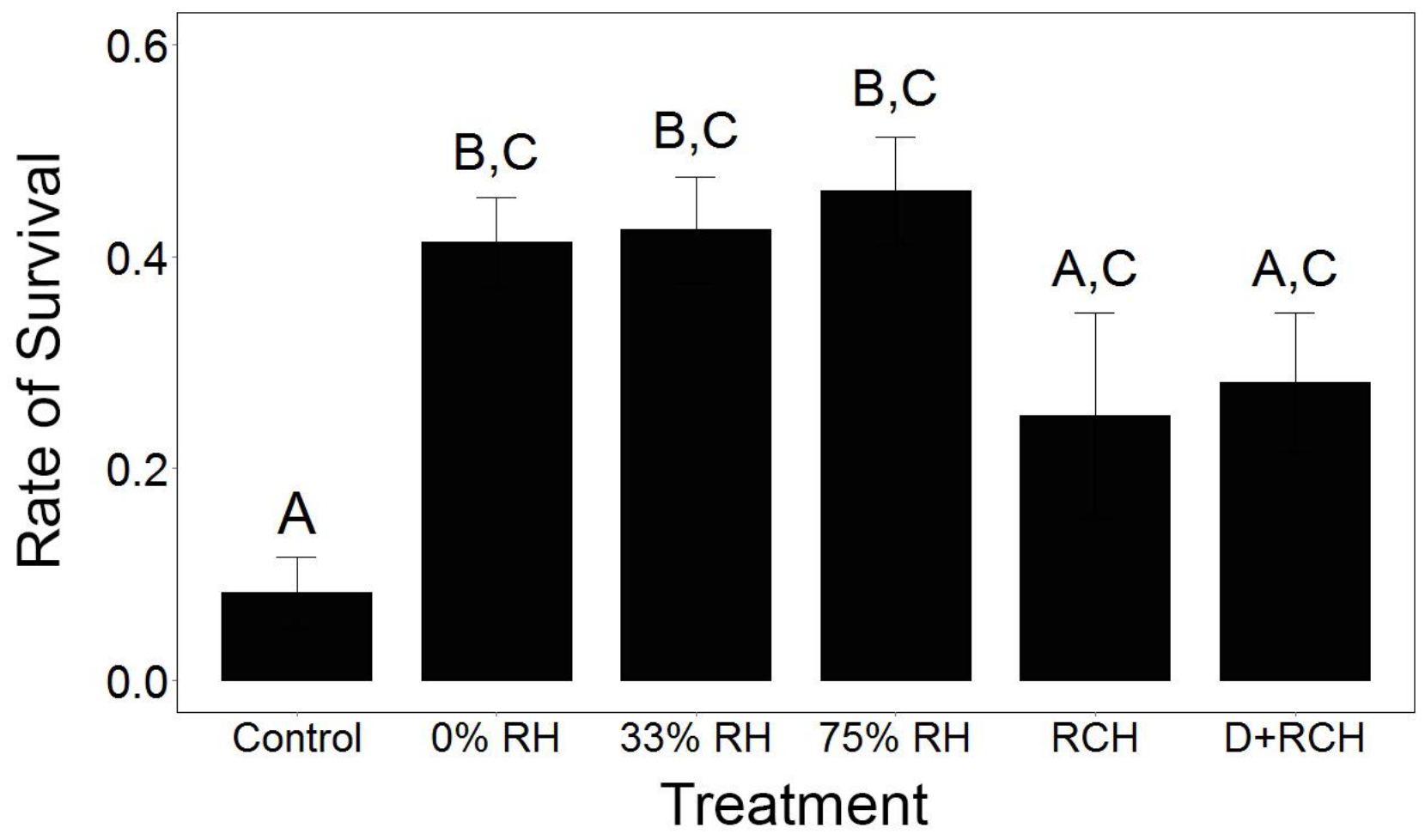


Figure 2

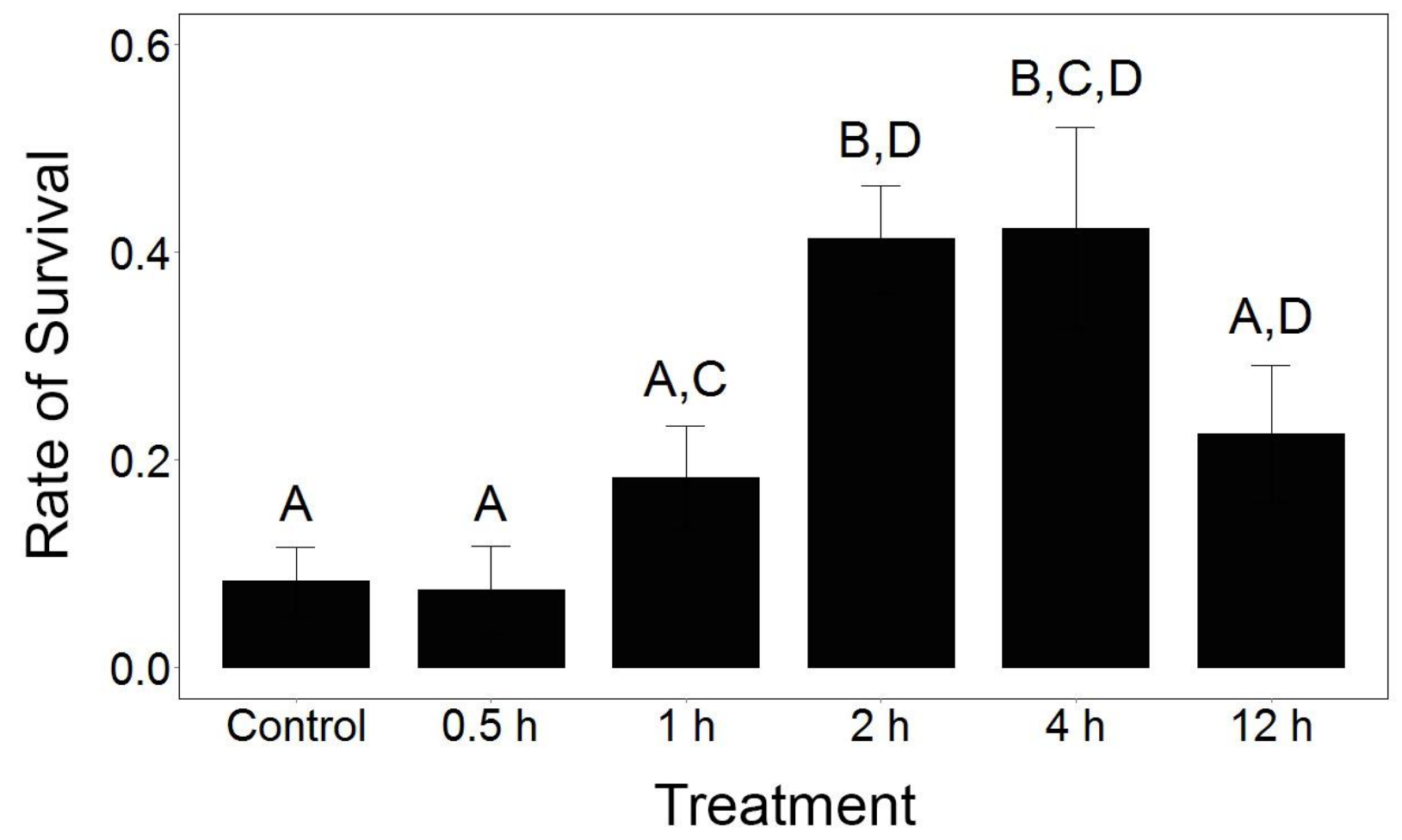


Figure 3

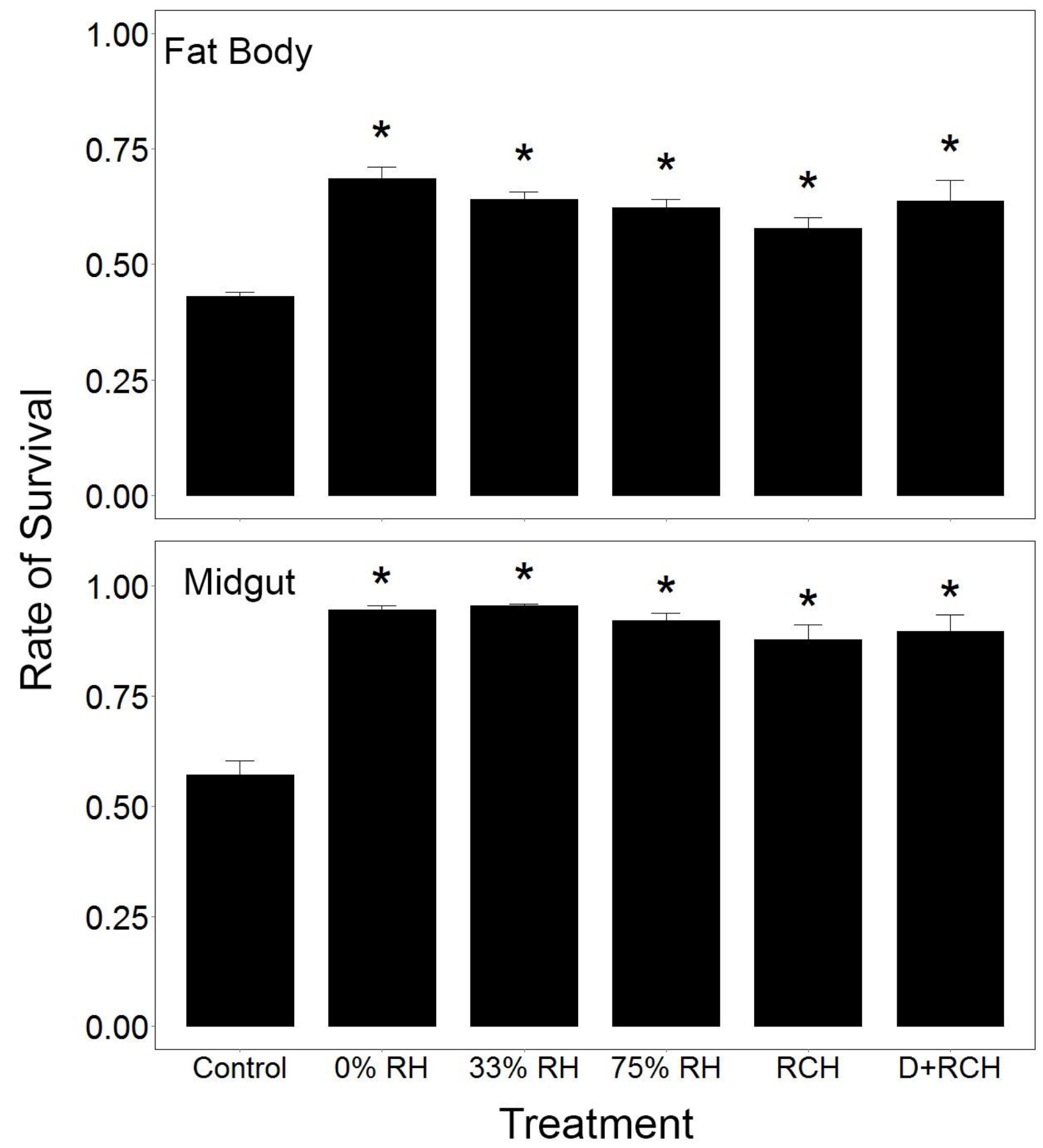


Figure 4

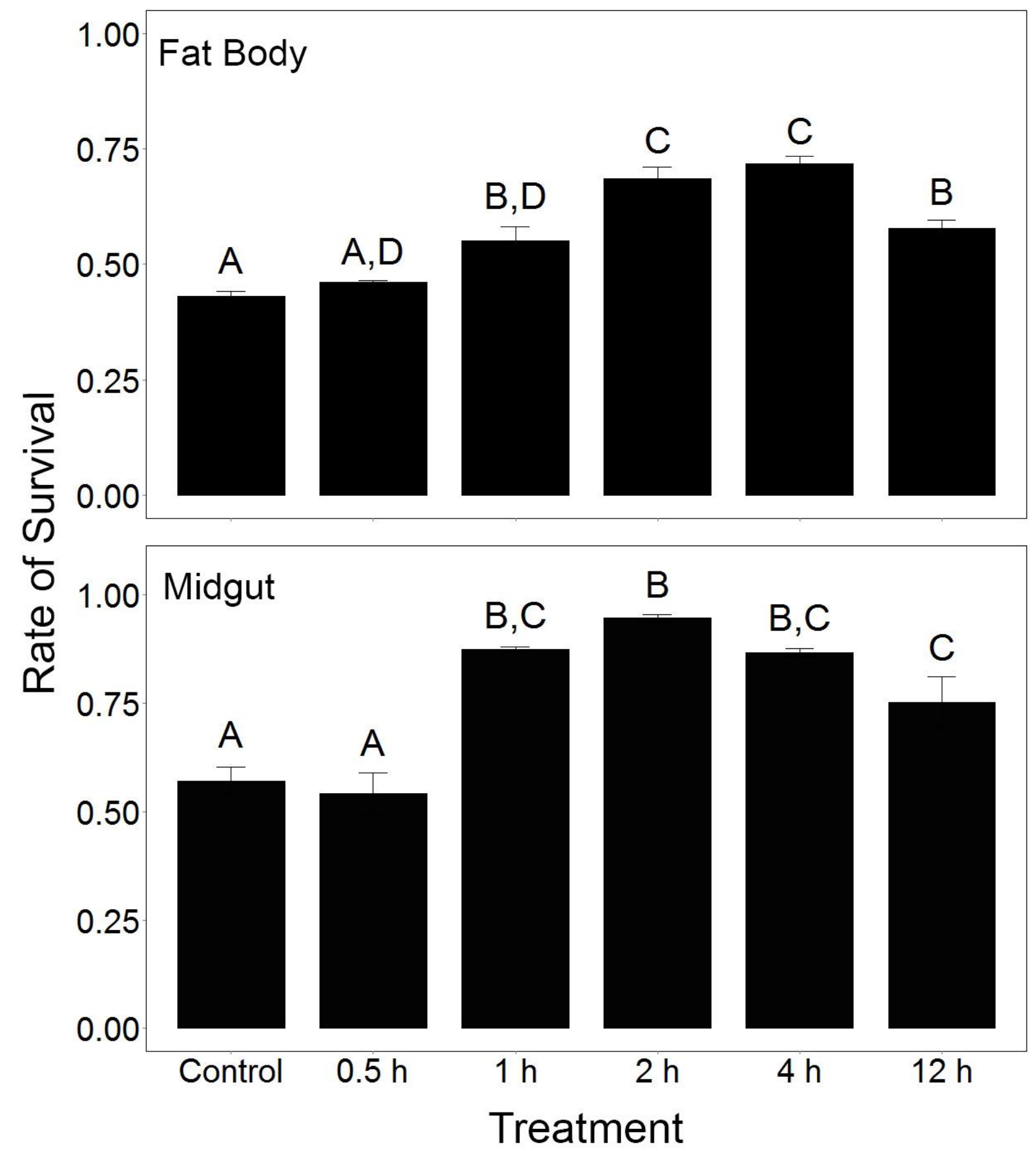


Figure 5

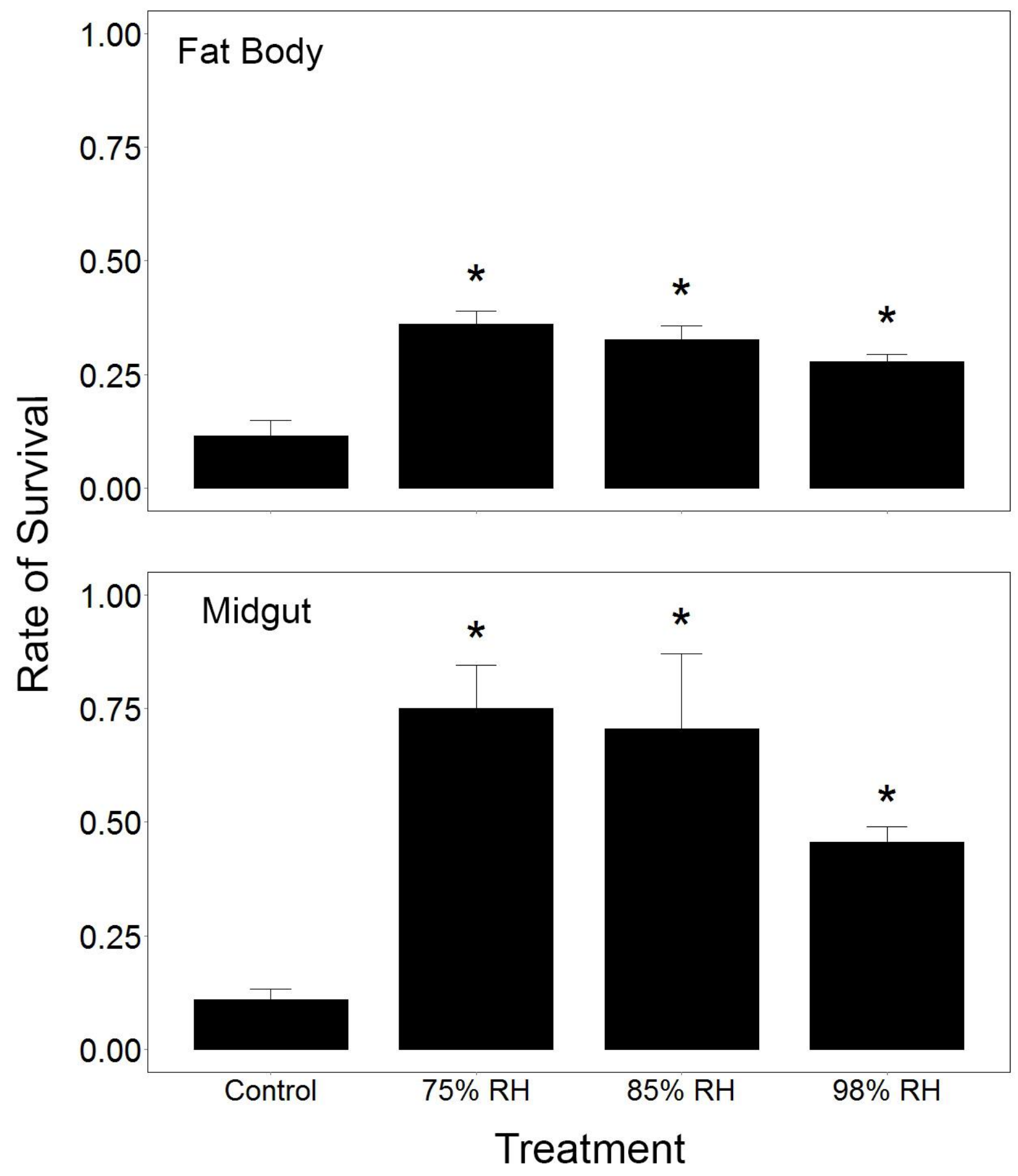


Figure 6

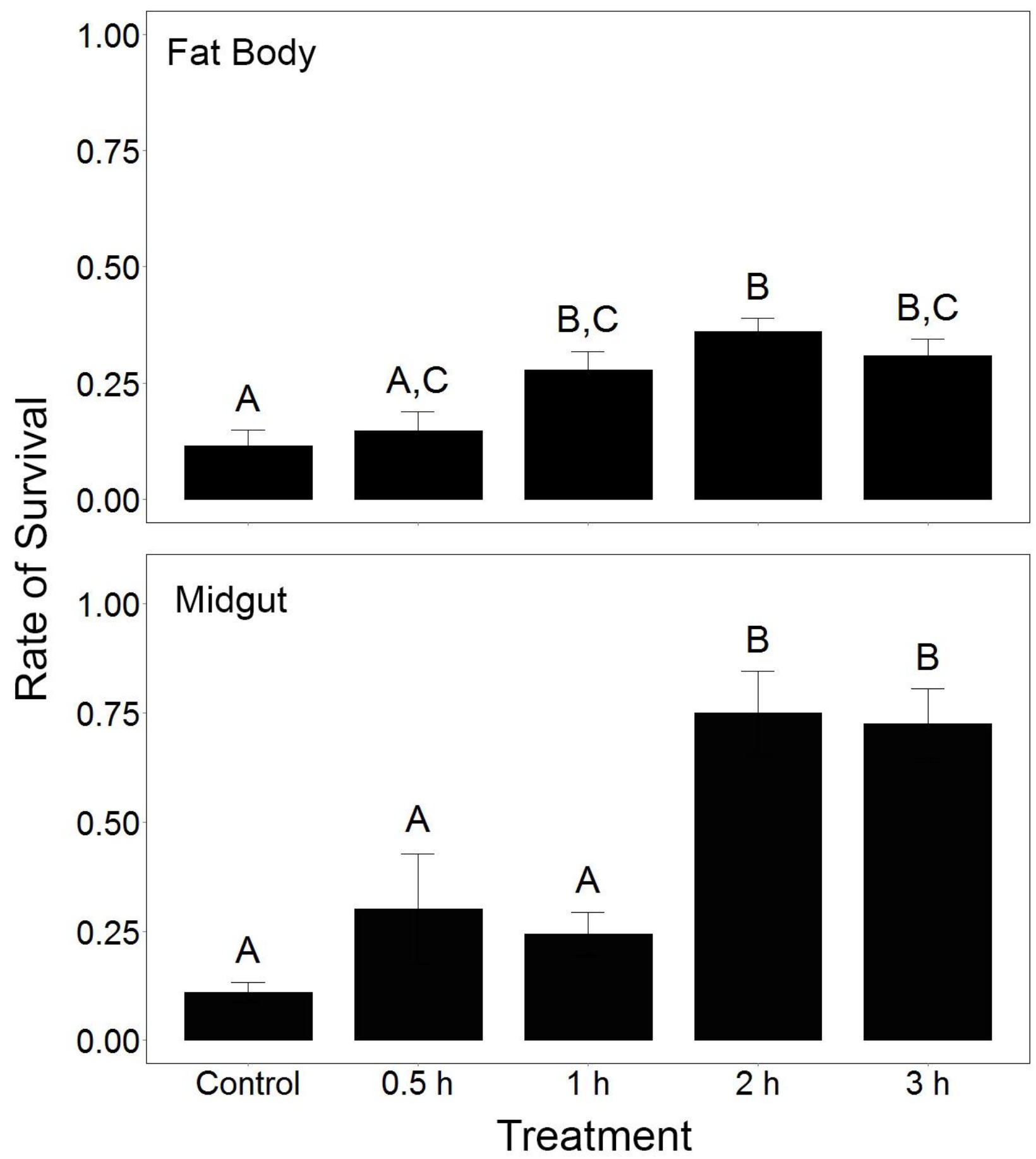




\section{Tables}

Table 1

Changes in hemolymph osmolality elicited by drought-induced RCH in larvae collected and treated in mid-October. Hemolymph was pooled from 2-3 larvae as needed; $\mathrm{n}=6$ per treatment. All treatments lasted $2 \mathrm{~h}$ unless noted. Control larvae were untreated. Predicted osmolality is calculated based on the control group measured hemolymph osmolality and the percent body water lost. Measured hemolymph osmolality values are mean \pm SEM. Statistical significance $(\mathrm{p} \leq 0.05)$ is denoted by $*$ and indicates the mean measured hemolymph osmolality of the treatment is distinguishable from the control.

\begin{tabular}{|c|c|c|c|c|c|c|}
\hline & Control & $\begin{array}{c}\text { Hydrated, } \\
\text { Cold } \\
\left(98 \% \mathrm{RH}, 0^{\circ} \mathrm{C}\right)\end{array}$ & $\begin{array}{l}\text { Mildly Dehydrated, } \\
\text { Warm } \\
\left(75 \% \mathrm{RH}, 22^{\circ} \mathrm{C}\right)\end{array}$ & $\begin{array}{l}\text { Dehydrated, } \\
\text { Warm } \\
\left(0 \% \mathrm{RH}, 22^{\circ} \mathrm{C}\right)\end{array}$ & $\begin{array}{l}\text { Dehydrated, } \\
\text { Cold } \\
\left(0 \% \mathrm{RH}, 0^{\circ} \mathrm{C}\right)\end{array}$ & $\begin{array}{c}\text { Dehydrated, } \\
\text { Prolonged, Warm } \\
\left(0 \% \mathrm{RH}, 4 \mathrm{~h}, 22^{\circ} \mathrm{C}\right)\end{array}$ \\
\hline $\begin{array}{l}\text { Body water lost } \\
\text { (percent) }\end{array}$ & 0 & 0.3 & 0.7 & 1.8 & 2.0 & 4.0 \\
\hline $\begin{array}{l}\text { Predicted osmolality } \\
\left(\mathrm{mOsm} \mathrm{kg}^{-1}\right)\end{array}$ & 573 & 574 & 576 & 583 & 584 & 593 \\
\hline $\begin{array}{l}\text { Measured hemolymph } \\
\text { osmolality }\left(\mathrm{mOsm} \mathrm{kg}^{-1}\right)\end{array}$ & $573 \pm 14$ & $588 \pm 7$ & $616 \pm 13$ & $620 \pm 14$ & $632 \pm 14 *$ & $656 \pm 8 *$ \\
\hline $\begin{array}{l}\text { Unexplained } \Delta \\
\text { osmolality }\left(\mathrm{mOsm} \mathrm{kg}^{-1}\right)\end{array}$ & 0 & 14 & 40 & 37 & 48 & 63 \\
\hline
\end{tabular}

\section{Table 2}

Cryoprotectant concentrations $\left(\mu \mathrm{mol} \mathrm{ml} \mathrm{m}^{-1}\right)$ in larvae collected and treated in mid-October. All treatments $(\mathrm{n}=6)$ lasted $2 \mathrm{~h}$, unless noted. Control larvae were untreated. No treatment elicited significant differences from controls $(\mathrm{p} \leq 0.05)$. 


\begin{tabular}{|c|c|c|c|c|c|}
\hline Control & Cold Shock & Dehydrated & $\begin{array}{c}\text { Moderately } \\
\text { Dehydrated } \\
(33 \% \mathrm{RH})\end{array}$ & $\begin{array}{c}\text { Mildly } \\
\text { Dehydrated } \\
(75 \% \mathrm{RH})\end{array}$ & $\begin{array}{c}\text { Dehydrated, } \\
\text { Prolonged } \\
(0 \% \mathrm{RH}, 4 \mathrm{~h})\end{array}$ \\
\hline
\end{tabular}

\begin{tabular}{|c|c|c|c|c|c|c|}
\hline Glucose & $1.2 \pm 0.6$ & $1.8 \pm 0.7$ & $1.5 \pm 0.8$ & $2.1 \pm 1.1$ & $0.8 \pm 0.5$ & $1.2 \pm 0.7$ \\
\hline Trehalose & $2.4 \pm 0.2$ & $2.6 \pm 0.3$ & $2.3 \pm 0.5$ & $2.5 \pm 0.3$ & $2.3 \pm 0.2$ & $2.2 \pm 0.4$ \\
\hline Sorbitol & $1.7 \pm 0.5$ & $2.1 \pm 0.6$ & $1.1 \pm 0.3$ & $2.4 \pm 0.8$ & $1.2 \pm 0.3$ & $0.7 \pm 0.2$ \\
\hline Glycerol & $473 \pm 51$ & $443 \pm 45$ & $545 \pm 44$ & $383 \pm 78$ & $407 \pm 67$ & $441 \pm 50$ \\
\hline
\end{tabular}




\section{References}

Bayley, M., \& Holmstrup, M. (1999). Water vapor absorption in arthropods by accumulation of myoinositol and glucose. Science, 285(5435), 1909-1911.

Bergmeyer, H.U., Gruber, W., \& Gutman, I. (1974). D-Sorbitol. In H.U. Bergmeyer (Ed.), Methods of Enzymatic Analysis, (pp. 1323-1326). New York: Academic Press.

Block, W. (1996) Cold or drought - the lesser of two evils for terrestrial arthropods? European Journal of Entomology, 93, 325-339.

Carpenter, J. F., \& Crowe, J. H. (1988). The mechanism of cryoprotection of proteins by solutes. Cryobiology, 25(3), 244-255.

Chen, C. P., Denlinger, D. L., \& Lee, R. E. (1987). Cold-shock injury and rapid cold hardening in the flesh fly Sarcophaga crassipalpis. Physiological Zoology, 60(3), 297-304.

Coast, G. M. (1988). Fluid secretion by single isolated Malpighian tubules of the house cricket, Acheta domesticus, and their response to diuretic hormone. Physiological Entomology, 13(4), 381-391.

Coulson, S. J., \& Bale, J. S. (1991). Anoxia induces rapid cold hardening in the housefly Musca domestica (Diptera: Muscidae). Journal of Insect Physiology, 37(7), 497-501.

Crowe, J. H., Crowe, L. M., Carpenter, J. F., Rudolph, A. S., Wistrom, C. A., Spargo, B. J., \& Anchordoguy, T. J. (1988). Interactions of sugars with membranes. Biochimica et Biophysica Acta (BBA)-Reviews on Biomembranes, 947(2), 367-384.

Danks, H. V. (2000). Dehydration in dormant insects. Journal of Insect Physiology, 46(6), 837852. 
Duman, J. G. (1977). The role of macromolecular antifreeze in the darkling beetle, Meracantha contracta. Journal of Comparative Physiology, 115(2), 279-286.

Duman, J., \& Horwath, K. (1983). The role of hemolymph proteins in the cold tolerance of insects. Annual Review of Physiology, 45(1), 261-270.

Fujiwara, Y., \& Denlinger, D. L. (2007). p38 MAPK is a likely component of the signal transduction pathway triggering rapid cold hardening in the flesh fly Sarcophaga crassipalpis. Journal of Experimental Biology, 210(18), 3295-3300.

Greenspan, L. (1977). Humidity fixed points of binary saturated aqueous solutions. Journal of Research of the National Bureau of Standards, 81(1), 89-96.

Hayward, S. A., Rinehart, J. P., Sandro, L. H., Lee, R. E., \& Denlinger, D. L. (2007). Slow dehydration promotes desiccation and freeze tolerance in the Antarctic midge Belgica antarctica. Journal of Experimental Biology, 210(5), 836-844.

Hazel, J. R., \& Williams, E. (1990). The role of alterations in membrane lipid composition in enabling physiological adaptation of organisms to their physical environment. Progress in Lipid Research, 29(3), 167-227.

Holmstrup, M., Bayley, M., Pedersen, S. A. \& Zachariassen, K. E. (2010). Interactions between cold, desiccation and environmental toxins. In D. L. Denlinger and R. E. Lee (Eds.), Low Temperature Biology of Insects, (pp. 166-187). Cambridge: Cambridge University Press.

Holmstrup, M., Costanzo, J. P., \& Lee, R. E. (1999). Cryoprotective and osmotic responses to cold acclimation and freezing in freeze-tolerant and freeze-intolerant earthworms. Journal of Comparative Physiology B, 169(3), 207-214. 
Hosokawa, N., Hara, Y., \& Mizushima, N. (2006). Generation of cell lines with tetracyclineregulated autophagy and a role for autophagy in controlling cell size. FEBS letters, 580(11), 2623-2629.

Itoh, T., Yamauchi, A., Miyai, A., Yokoyama, K., Kamada, T., Ueda, N., \& Fujiwara, Y. (1994). Mitogen-activated protein kinase and its activator are regulated by hypertonic stress in MadinDarby canine kidney cells. Journal of Clinical Investigation, 93(6), 2387.

Karow, A. M. (1991). Chemical cryoprotection of metazoan cells. BioScience, 41(3), 155-160.

Koštál, V., Havelka, J., \& Šimek, P. (2001). Low-temperature storage and cold hardiness in two populations of the predatory midge Aphidoletes aphidimyza, differing in diapause intensity. Physiological Entomology, 26(4), 320-328.

Koštál, V., Šimek, P., Zahradníčková, H., Cimlová, J., \& Štětina, T. (2012). Conversion of the chill susceptible fruit fly larva (Drosophila melanogaster) to a freeze tolerant organism. Proceedings of the National Academy of Sciences, 109(9), 3270-3274.

Lee, R. E., Damodaran, K., Yi, S-X., \& Lorigan, G. A. (2006). Rapid cold-hardening increases membrane fluidity and cold tolerance of insect cells. Cryobiology, 52(3), 459-463.

Lee, R. E., \& Denlinger, D. L. (Eds.). (1991). Insects at Low Temperatures. New York: Chapman \& Hall.

Lee, R. E., Chen, C. P., \& Denlinger, D. L. (1987). A rapid cold-hardening process in insects. Science, 238(4832), 1415-1417.

Lee, R. E., Elnitsky, M. A., Rinehart, J. P., Hayward, S. A., Sandro, L. H., \& Denlinger, D. L. (2006). Rapid cold-hardening increases the freezing tolerance of the Antarctic midge Belgica antarctica. Journal of Experimental Biology, 209(3), 399-406. 
Lee, R. E., \& Denlinger, D. L. (2010). Rapid cold-hardening: ecological significance and underpinning mechanisms. In D. L. Denlinger \& R. E. Lee (Eds.), Low Temperature Biology of Insects, (pp. 35-58). Cambridge: Cambridge University Press.

Levis, N. A., Yi, S. X., \& Lee, R. E. (2012). Mild desiccation rapidly increases freeze tolerance of the goldenrod gall fly, Eurosta solidaginis: evidence for drought-induced rapid coldhardening. Journal of Experimental Biology, 215(21), 3768-3773.

Maiuri, M. C., Zalckvar, E., Kimchi, A., \& Kroemer, G. (2007). Self-eating and self-killing: crosstalk between autophagy and apoptosis. Nature Reviews Molecular Cell Biology, 8(9), 741752.

M'Baye, G., Mély, Y., Duportail, G., \& Klymchenko, A. S. (2008). Liquid ordered and gel phases of lipid bilayers: fluorescent probes reveal close fluidity but different hydration. Biophysical Journal, 95(3), 1217-1225.

Meijer, A. J., \& Dubbelhuis, P. F. (2004). Amino acid signaling and the integration of metabolism. Biochemical and Biophysical Research Communications, 313(2), 397-403.

Michaud, M. R., \& Denlinger, D. L. (2007). Shifts in the carbohydrate, polyol, and amino acid pools during rapid cold-hardening and diapause-associated cold-hardening in flesh flies (Sarcophaga crassipalpis): a metabolomic comparison. Journal of Comparative Physiology B, 177(7), 753-763.

Misener, S. R., Chen, C. P., \& Walker, V. K. (2001). Cold tolerance and proline metabolic gene expression in Drosophila melanogaster. Journal of Insect Physiology, 47(4), 393-400.

Onodera, J., \& Ohsumi, Y. (2005). Autophagy is required for maintenance of amino acid levels and protein synthesis under nitrogen starvation. Journal of Biological Chemistry, 280(36), 31582-31586. 
Overgaard, J., Malmendal, A., Sørensen, J. G., Bundy, J. G., Loeschcke, V., Nielsen, N. C., \& Holmstrup, M. (2007). Metabolomic profiling of rapid cold hardening and cold shock in Drosophila melanogaster. Journal of Insect Physiology, 53(12), 1218-1232.

Prick, T., Thumm, M., Kohrer, K., Haussinger, D., \& Vom Dahl, S. (2006). In yeast, loss of Hog1 leads to osmosensitivity of autophagy. Biochemical Journal, 394, 153-161.

Rabinowitz, J. D., \& White, E. (2010). Autophagy and metabolism. Science, 330(6009), 13441348.

Ramlov, H. \& Lee, R. E. (2000). Extreme resistance to desiccation in overwintering larvae of the gall fly, Eurosta solidaginis (Diptera, Tephritidae). Journal of Experimental Biology 203, 783789.

Ring, R. A. \& Danks, H. V. (1994). Desiccation and cryoprotection: overlapping adaptations. CryoLetters 15, 181-190.

Rojas, R. R., Lee, R. E., \& Baust, J. G. (1986). Relationship of environmental water content to glycerol accumulation in the freezing tolerant larvae of Eurosta solidaginis (Fitch). CryoLetters, 7, 234-245.

Salt, R. W. (1961). Principles of insect cold-hardiness. Annual Review of Entomology, 6(1), 5574.

Shrode, L. D., Gan, B. S., D’Souza, S. J., Orlowski, J., \& Grinstein, S. (1998). Topological analysis of NHE1, the ubiquitous $\mathrm{Na}+\mathrm{H}+$ exchanger using chymotryptic cleavage. American Journal of Physiology-Cell Physiology, 275(2), 431-439.

Sinclair, B. J., \& Chown, S. L. (2003). Rapid responses to high temperature and desiccation but not to low temperature in the freeze tolerant sub-Antarctic caterpillar Pringleophaga marioni (Lepidoptera, Tineidae). Journal of Insect Physiology, 49(1), 45-52. 
Teets, N. M., Elnitsky, M. A., Benoit, J. B., Lopez-Martinez, G., Denlinger, D. L., \& Lee, R. E. (2008). Rapid cold-hardening in larvae of the Antarctic midge Belgica antarctica: cellular coldsensing and a role for calcium. American Journal of Physiology-Regulatory, Integrative and Comparative Physiology, 294(6), 1938-1946.

Teets, N. M., Peyton, J. T., Colinet, H., Renault, D., Kelley, J. L., Kawarasaki, Y., ... \& Denlinger, D. L. (2012). Gene expression changes governing extreme dehydration tolerance in an Antarctic insect. Proceedings of the National Academy of Sciences, 109(50), 20744-20749.

Teets, N. M., Yi, S-X., Lee, R. E., \& Denlinger, D. L. (2013). Calcium signaling mediates cold sensing in insect tissues. Proceedings of the National Academy of Sciences, 110(22), 9154-9159.

Uhler, L. D. (1951). Biology and ecology of the goldenrod gall fly: Eurosta solidaginis (Fitch). Cornell University Agricultural Experiment Station Memoir 300: 1-47.

Watanabe, M., Kikawada, T., Minagawa, N., Yukuhiro, F., \& Okuda, T. (2002). Mechanism allowing an insect to survive complete dehydration and extreme temperatures. Journal of Experimental Biology, 205(18), 2799-2802.

Wehner, F., Olsen, H., Tinel, H., Kinne-Saffran, E., \& Kinne, R. K. H. (2003). Cell volume regulation: osmolytes, osmolyte transport, and signal transduction. (pp. 1-80). Springer Berlin Heidelberg.

Williams, J. B., \& Lee, R. E. (2005). Plant senescence cues entry into diapause in the gall fly Eurosta solidaginis: resulting metabolic depression is critical for water conservation. Journal of Experimental Biology, 208(23), 4437-4444.

Williams, J. B., Ruehl, N. C., \& Lee, R. E. (2004). Partial link between the seasonal acquisition of cold-tolerance and desiccation resistance in the goldenrod gall fly Eurosta solidaginis (Diptera: Tephritidae). Journal of Experimental Biology, 207(25), 4407-4414. 
Yi, S-X., \& Lee, R. E. (2003). Detecting freeze injury and seasonal cold-hardening of cells and tissues in the gall fly larvae, Eurosta solidaginis (Diptera: Tephritidae) using fluorescent vital dyes. Journal of Insect Physiology, 49(11), 999-1004.

Yi, S-X., \& Lee, R. E. (2004). In vivo and in vitro rapid cold-hardening protects cells from coldshock injury in the flesh fly. Journal of Comparative Physiology B, 174(8), 611-615. 